\title{
Bullied Students and Their Self-Esteem
}

\author{
Jerald C. Moneva \\ Department of Education-Mandaue City Division \\ Mandaue City, Cebu, Philippines \\ Tel: +63908-927-3038Ｅ-mail: Freezingfire1979@gmail.com
}

http://orcid.org/0000-0003-0936-2625

\author{
Jhon France Larrie Calunod \\ Jagobiao National High School \\ Jagobiao, Mandaue City, Cebu, Philippines
}

Tel: +63927-640-5269Ｅ-mail: Franceprance100@gmail.com

Judima A. Sumayang

City of Naga, Cebu, Philippines

E-mail: Judima.sumayang@deped.gov.ph

Received: February 11, 2020 Accepted: March 28, 2020 Published: April 13, 2020

doi:10.5296/ijssr.v8i2.16840 URL: http://dx.doi.org/10.5296/ijssr.v8i2.16840

\begin{abstract}
Bullying is one of the major problems among students in school. Bullies use scare tactics to bully smaller or weaker students that might affect their esteem. High self-esteem and positive self-concept are important characteristics of an individual. The study intends to determine the association of perceived bullying and self-esteem of the junior high school students in Jagobiao National High School. This study used the quantitative approach descriptive survey design to determine the association between level of perceived bullying and their self-esteem. The researchers used checklist as the research instrument. The checklist has two parts consisting 10 indicators in each part. The first 10 indicators are about perceived bullying and the next 10 parts are all about students' self-esteem. The data gathered will be treated with the use sum, frequency and simple percentage, weighted mean and chi-square. The result shows that the students were sometimes bullied by lies and false rumors that were told by others to
\end{abstract}




\section{Macrothink

hurt them. The students sometimes do not trust their strength and capabilities. There is no significant association between bullying and students' self-esteem. Perceived bullying among students has nothing to do with their self-esteem.

Keywords: perceived bullying, self-esteem, students 


\section{Rationale}

Bullying is one of the major problems among students in school. Bullies use scare tactics to bully smaller or weaker students. Bullying is observable verbally, emotionally, and physically. Bullying is an abusive treatment of weaker students by stronger students.

Bullying is a major problem of the society today. Bullying is not good because it could ruin many people's lives. Based on the researchers experience and observation on children's self-esteem, victims of bullying think negatively. They get drowned by the thought that people might hurt them. They are wondering why other students keep on doing unnecessary things to them or other students harassed them. They are into thinking what really the problem is. Bullying usually happens on kids or children who have experiences of being bullied. They are usually lack or poor in socialization caused by their traumatic experiences of being bullied. Students want to have a school with safe environment and free from bullying. Bullying is not a new issue that students face in school. Weaker bullied increased feeling of sadness and loneliness and lost interest in activities they use to enjoy.

On the other hand, high self-esteem and positive self-concept are important characteristics of an individual. Bullying in school is not new and it has been increasing until this time (Tukmen, Dokgoz, Akgoz, Eren, Vural, \& Dolot, 2013). In the adolescence, the most frequently used was verbal aggression, especially when one is being called names made fun of or teased in a hurtful way (Brito \& Oliveira, 2013). High self-esteem can lead to bullying to both genders (Ang, Chong, Lee, Tang, \& Liew, 2018).

In the study the researchers intend to determine the association of perceived bullying and self-esteem of the junior high school students in Jagobiao National High School.

\subsection{Theoretical Background}

The study is anchored on two theories. "A theory of bullying" is formulated by a French political theorist Alexis de Tocqueville and Helmut Shoek in 2010.It states that bullying problem is all about jealousy. The other theory is "Personality Theory" formulated by William James in 1890. It states how students view their self-image.

Students who are bullies desire to have what someone else has. According to theory of Alexis de Tocqueville and Helmut Shoek bullying is more likely to female because they tend to compete for the attention of males. Bully students will ensure that the bullied students will not enjoy their daily activities nor show their skills and abilities.

"A theory of bullying "states how the bullied students are getting weak. Most of the bullied students lost their interest in school. Theory states that enviousness is the main cause or root of bullying

Students with high self-esteem can help students mold up their self-image. Self-esteem describes as our self-image whether we approve it or not. The idea of self-esteem is to define how students like their selves or value it.

"James Personality theory" states that self-esteem is important to everyone because if 
students don't have self-esteem, they can be self-seeking. Self-seeking may lead the students desire to please or to be noticed. In addition, students become envy because of their consciousness.

Alexis de Tocqueville and Helmut Shoek stated that bullies have the attributes to hurt other students. Bullies make sure that other students do not use their abilities or attributes to enjoy their lives. Helmut Shoek added that envy person mostly the bullies want to have what others have. According to William James, self-esteem is how we view our self-image; bullies always want to be the center of attraction. In other words, they are attention seekers. They hurt other students because they want to seek attention and like to become superiors to other students.

\subsection{Statement of Purpose}

This study intends to assess the association between level of students who are being bullied and their self-esteem.

In particular, the study seeks to answer the following question

1. What is the level of self-esteem of the senior high students?

2. What is the level of perceived bullying of senior high students?

3. Is there an association between level of perceived bullying and their self-esteem?

\subsection{Review of Related Literature}

Collective learning can boost students' self-esteem (Nurhayati, Rosmaiyadi, \& Buyung 2017) High self-esteem can cause bullying to the students who have low self-esteem (Ang et al, 2018). One of the challenges that students would face is maintaining their self-esteem (Minev, Petrova, Mineva, Petkua, \& Strebkova, 2018). Improving one's self-esteem is beneficiary for the students' life success (Orth \& Robins, 2014). Having a positive environment and feedback will lead to the students' high level of self-confidence (Karimi \& Saadatmand, 2014). It is proven that family and relatives can make a difference on academic performance to adolescents' life (Mello, Monteiro, \& Pinto, 2018). Self-esteem could help students overcome challenges in life (Manna, Falgares, Ingoglia, Como, \& Santis, 2016). However, the more students enjoy in every activities in life, the more they have high self-esteem (Sari, Erici, Soyer, \& Eskiler, 2014). It needs a high self-esteem to overcome the hurdles students would face (Uba, Yaacob, Juhari, \&Talil, 2018). Students who have high self-esteem believe on their own capabilities and have a positive mindset (Rathasari \&Andriansya, 2014). High self-esteem can lead students to have positive relationships in each individual (Greenacre, Tung, \& Chapman, 2014). Achieving high self-esteem needs to have a strong relationship towards others (Sharma \& Agarwala, 2015). The problem of self-esteem exists to everyone (Khan, Khan, Khan, \& Saif, 2015). Individuals need to understand that self-esteem might change at different developmental periods (Robins \& Tzresniewski, 2005). Students who have low self-esteem are more likely to have mental illness (Masselink, Roekel, \& Oldehinkel 2017).

Bullying has the largest issue among students (Tukmen, Dokgoz, Akgoz, Eren, Vural, \& 


\section{MInstitute Macrothink $_{\text {Int }}$}

International Journal of Social Science Research

ISSN 2327-5510

2020, Vol. 8, No. 2

Dolot, 2013). A striking number of students have stated that they had been bullied (Brito \& Oliveira, 2013). Bullying is more frequent in schools (Koonce \& Mayo, 2013). Experiences on interparental violence can make students' self-esteem low, depressed, anxious and less assertive (Baldry, 2003). Students who have constantly experienced being bullied have lower self-esteem and higher depressive symptoms than students who had not been bullied. Students who suffer from bullying may affect their academic achievement similarly with the bullies (Raqqad, Barini, \& Talahin, 2017). Bullying is a common problem to students (Wolke, Woods, Bloomfield, \& Karstadt, 2001). The most common bullying forms are physical abuse and verbal abuse (Aulia 2016). Students who witnessed victimization may feel anxious and may think that they will be victimized too (Rivers, Poteat, Noret, \& Ashurst, 2009). Emotions like envious can lead to students bullying (Ahmed, Hussain, Ahmed, \& Tabassum, 2015). In addition, one of the most causes of bullying was dominancy (Jan \& Hussain, 2015). Bullied students are more likely have mental and emotional problems than students who are not bullied (Gini \& Pozzli, 2013). However, the several factors that is related to the different types of bullying can be easily controlled or easily persuaded to change (Ando \& Asakura, 2005). With appropriate intervention, the well-being of the students can lead them to become happy individuals (Smith, 2016). Likewise, bullying is one of the most common factors of students' unsatisfactory performance (Zalba et al, 2015).

\section{Research Method}

\subsection{Design}

This research used the quantitative approach descriptive survey design to determine the association between level of perceived bullying and the level of self-esteem among students.

\subsection{Environment}

The study was conducted in Jagobiao National High School in the senior school building particularly in grade 11 and 12. The Jagobiao National High School grade 11 has 5 strands which include Accountancy and Business Management (ABM), Humanities and Social Science (HUMSS), General Academic Strand (GAS), Technical Vocational Livelihood (TVL) And, STEM. The grade 12 has 3 strands which are HUMSS, ABM and, GAS.

\subsection{Respondents}

The research respondents were the grade 11 and 12 students in the senior high school. With complete enumeration, 200 of students out of 249 answered the questionnaire willingly.

\subsection{Instruments}

The researchers devised a researcher-made tool consist of 10 indicators in each variable. The survey questionnaire is a checklist type that is composed of two variables which are Perceived Bullying and Student's Self-esteem. The respondents is asked to put check mark on the blank provided corresponds to any number written above each item that will best describe their opinions. The choices are always, sometimes and never. The respondents were given at least 10 minutes to answer the given survey questionnaire. 


\subsection{Data Gathering Procedures}

The researchers asked first the permission of the school head and to all of the senior high school teachers. When the letter request was approved the researchers conducted the data gathering from the students of senior high school. The researchers conducted this study room to room. The specific time and day when the researcher conducted the study is exactly 7:50AM to 8:50 AM during Mondays, Wednesdays, and Fridays and 9:30 AM to 11:30 AM during Tuesdays and Thursdays. The respondents are guided by the direction that the researchers gave. The respondents were assured that their answers only used in the study shall be used without utmost confidence and trust.

\subsection{Statistical Treatment}

The researcher used weighted mean to get the level of self-esteem and perceived bullying; and chi-square to identify the association between Bullied students and their self esteem

\subsection{Data Analysis and Discussion}

Table 1. Experience bullying

\begin{tabular}{lll}
\hline Indicators & WM & Interpretation \\
\hline 1.I was teased by my face in nasty ways & 2.27 & sometimes \\
2.Lies and false rumors were told about me to others to hurt me & 2.43 & sometimes \\
3.I was hurt by someone trying to break up my relationship with friends & 2.13 & sometimes \\
4.I was made to feel afraid/intimate by what someone said he/she do to me & 2.21 & sometimes \\
5.I was deliberately hurt physically by someone and/or by a group ganging up on me & 2.23 & sometimes \\
6.I was called names in nasty ways or name calling & 2.12 & sometimes \\
7.Someone told me he/she wouldn't like me unless I did what he/she said & 2.18 & sometimes \\
8.My things were deliberately damaged, destroyed or stolen & 2.23 & sometimes \\
9.I was teased by the used of my parents" names & 2.32 & sometimes \\
10.Bullies are always looking fun at me & 2.29 & sometimes \\
Total & 2.24 & sometimes \\
\hline
\end{tabular}

$\mathrm{N}=200$ Scale: $1.00-1.67$ (Never), 1.68- 2.34 (Sometimes), $2.35-3.00$ (Always)

The first highest weighted mean reveals that the students sometimes were hurt by someone trying to break up their relationship with friends. Second highest weighted mean shows that the students sometimes were teased by the used of their parents' names. The third and last highest weighted mean stated that the students were sometimes bullied because bullies are always looking fun at them. In addition, the three lowest weighted mean was also shown in the table. The first lowest weighted mean shows that the students sometimes were called names in nasty ways or name calling. The second lowest weighted mean interpreted that the students sometimes were hurt by someone trying to break up their relationship with friends and the third lowest weighted mean indicate that the student sometimes were told that he/she wouldn't like them unless they did what he/she said. Dominance is the principal cause of 
bullying (Jan \& Hussain, 2015). Bullying has the students' biggest problem (Tukmen, Dokgoz, Akgoz, Eren, Vural, \& Dolot, 2013) and for schools bullying is more common (Koonce \& Mayo, 2013).

Table 2. Experience Bullying

\begin{tabular}{lll}
\hline INDICATORS & Frequency & Percent \\
\hline Always Bullied & 0 & 0 \\
Sometimes Bullied & 43 & 21.5 \\
Not Bullied & 157 & 78.5 \\
Total & 200 & 100.0 \\
\hline
\end{tabular}

The table above shows the percentage of the respondents who have been always bullied is $0 \%$. $21.5 \%$ of them are sometimes being bullied while there are $78.5 \%$ of them have not been bullied at all. It concludes that most of the students of Jagobiao National High school have not experienced bullying before. Thus, the following respondents can be considered as an ideal part of this study.

Table 3. Students' Self Esteem

\begin{tabular}{lll}
\hline Indicators & WM & interpretation \\
\hline 1.I do not trust my strength and capabilities & 2.20 & sometimes \\
2. I do not give value with my ideas because it seems like meaningless. & 2.20 & sometimes \\
3.I feel that my concern is not valuable to others & 1.97 & sometimes \\
4. I take negative attitude towards myself & 1.94 & sometimes \\
5.I feel that I don't have a number of good qualities & 2.10 & sometimes \\
6.I am not able to do things as well as most people & 2.03 & sometimes \\
7.All in all, I am inclined to feel that I am failure & 2.10 & sometimes \\
8.I feel I do not have much to be proud of & 2.01 & sometimes \\
9.I certainly feel useless at times & 2.16 & sometimes \\
10.At times I think that I am not good at all & 2.03 & sometimes \\
Total & 2.07 & sometimes \\
\hline
\end{tabular}

$\mathrm{N}=240$ Legend: 1 - 1.67 (Never), 1.68- 2.34 (Sometimes), 2.35 - 3 (Always)

The first highest weighted mean shows that the students sometimes do not trust their strength and capabilities. The second highest weighted mean shows that the students sometimes feel useless at times. The third and last highest weighted mean reveals that the students sometimes feel that they don't have a number of good qualities. On the other hand, there are also three lowest weighted mean that shown in the table. The first lowest weighted mean shows that the 
students sometimes take negative attitude towards their selves. The second lowest weighted mean stated that the students sometimes they feel that their concern is not valuable to others. Lastly, the third lowest weighted mean interpreted that the students sometimes at times they think that they are not good at all. Anyone has the issue of self-esteem (Khan, Khan, Khan, \& Saif, 2015). One of the problems that students would face is maintaining their self-esteem (Minev, Petrova, Mineva, Petkua, \& Strebkova, 2018). In contrary having a positive feedback will lead to a students' high level of self-esteem (Karimi \& Saadatmand 2014).

Table 4. Level of students' Self-Esteem

\begin{tabular}{lll}
\hline Indicators & Frequency & Percent \\
\hline Affected & 1 & .5 \\
Moderately Affected & 90 & 45 \\
Not Affected & 109 & 54.5 \\
Total & 200 & 100.0 \\
\hline
\end{tabular}

The table above illustrated that $.5 \%$ of respondents answered that their self-esteem is affected whenever they got bullied. $45 \%$ of the respondents answered that they are moderately affected when they are being bullied while $54.5 \%$ of them are not affected at all. Since there are $54.5 \%$ and $45.5 \%$ of the respondents answered that they are moderately affected and not affected. Therefore, whenever the students are being bullied in school, their self-esteem is not affected at all.

Table 5. Bullied Students and their self-esteem

\begin{tabular}{llll}
\hline & Value & df & Asymp. Sig. (2-sided) \\
\hline Pearson Chi-Square & $.527^{\mathrm{a}}$ & 2 & .768 \\
Likelihood Ratio & .737 & 2 & .692 \\
Linear-by-Linear Association & .361 & 1 & .548 \\
N of Valid Cases & 200 & & \\
\hline
\end{tabular}

a. 2 cells $(33.3 \%)$ have expected count less than 5 . The minimum expected count is .22 .

The table above shows that the $p$-value (.768) is greater than significant level $(\alpha=0.5)$. There is no significant association between bullying and student's self-esteem. Some researchers showed that the students with a high level of self-esteem believe in their own abilities and have a positive mindset (Rathasari \& Andriansya, 2014). High self-esteem leads students to have a positive relationship (Greenacre, Tung, \& Chapman, 2014). To attain high self-esteem must have a strong relationship with others (Sharma \& Agarwala, 2015). 


\section{Findings}

The data reveals that having low self-esteem of senior high school students is not depending on bullying. The number of bullied students is more than number of students who are not bullied.

The result of overall mean has been interpreted as sometimes. Students do not trust their strength and capabilities in terms of school related activities. Most of the students do not trust themselves because they think that they don't have a number of good qualities to face the hurdles.

There is no positive association between perceived bullying and self-esteem. Base on the findings, bullying is not the reason on getting lower self-esteem of senior high school students. There are students in which their self-esteem is not affected by bullying

\section{Conclusion}

Self-esteem is essential among students in their disposition and in their studies. Meanwhile, bullying is very frequent in school. However, bullies do not affect the self-confidence of the students in Jagobiao National High School. Bullying is the students common problem but this study shows that the students of Jagobiao National High School are accustomed to bullying because bullying to them is not an issue, some forms of bullying to them is not ordinary and tolerable. Some of students also are amenable to adapt. Students tend to be reserved when being bullied because they were prone on bullying. Students are getting used to be bullied and some of them just enjoying it because they are already aware about how bullying can affect their self-esteem. Nevertheless, there are still students who get bullied and are also getting low self-esteem. In general, the existing bullying doesn't affect the self-esteem of the students in Jagobiao National High School.

\section{Recommendation}

The following are the recommendations of the researcher based on the gathered data:

Students must have a positive mindset and should take a positive attitude in dealing with problems. They must believe in their own strength and capabilities. Students must believe in their worth and avoid self-doubt.

Teachers must motivate their students when they feel down and show to their students that they accept them for who they are and teachers must teach students to cope with mistakes and failure.

Parents should consult their students so that they can assess their mental health.

\section{References}

Aalsma, M. C., \& Brown, J. R. (2008). What is bullying? Journal of Adolescent Health, 43, 101-102. https://doi.org/10.1016/j.jadohealth.2008.06.001

Ahmed, M., Hussain, S., \& Tabassum, R. (2012). Impact of bullying on the performance of the students as primary level in sindh. Journal of Education and Practice, 3(3), 17-24. 
Retrieved from https://www. researchgate.net/publication/228518569

Ando, M., Asakura, T., \& Morton, B. S. (2003). Psychosocial influences on physical, verbal, and indirect bullying among Japanese early adolescents. Journal of Early Adolescents, 25(3), 268-297. https://doi.org/10.1177/0272431605276933

Ang, C. S., Chong, C. P., Cheong, S. W., Lee, C. Y., Tang, Z. H., \& Liew, C. Y. (2018). Self-esteem and tendency of bullying among primary school children. Romanian Journal of Applied Psychology, 20(1), 11-17. https://doi.org/10.24913/rjap.20.1.03

Aulias, F. (2016). Bullying experience in primary school children schoulid. Indonesian Journal of School Counseleng, 1(1), 28-32. https://doi.org/10.23916/schoulid.v1i1.37.28-32

Baldry, A. (2003). Bullying in school and exposure to domestic violence. Department of Social Psychology, University of Rome La Sapienza; Via dei Marsi, 78, 00185, Italy. 713-732. https://doi.org/10.1016/S0145-2134(03)00114-5

Brito, C., \& Oliveira. (2016). Bullying and self-esteem in adolescents from public schools. Journal De Pediatria, 89(6), 601-607. https://doi.org/10.1016/j.jped.2013.04.001

Gin, G., \& Pozzoli, T. (2013). Bullied children and psychosomatic Problems: A meta-analysis. American Academic of Pediatrics, 132, 720-729. https://doi.org/10.1542/peds.2013-0614

Greenarce, L., Tung, N. M., \& Chapman, T. (2014). Self-confidence and the ability to influence. Academy of Marketing Studies Journal, 18(2), 169-180. Retrieved from https://www.reserachgate.net/publication/286318041

Jan, A., \& Hussain, S. (2015). Bullying in elementary school: Its causes and effects on students. Journal of Education and Practice, 6(19), 43-56. Retrieved from https://files.erici.edu.gov/fulltext/Ej1079521.pdf

Karimi, A., \& Saadatmand, Z. (2014). The relationship between self-confidence with achievement based on academic motivation. Kuwait Chapter of Arabian Journal of Business and Management Review, 4(1), 201-214. Retrieved from https://www.arabianjbmr.com/pdfs/KD_VOL4_1/19

Khan, M. R., Khan, I., Khan., D. S., \& Saif, N. (2015). The self-esteem: a review of literature. International Journal of African and Asian Studies, 9, 1-3. Retrieved from https://iiste.org/journal/index.php/JAAS/Article/view/22747

Koonce, G., \& Mayo, S. (2013). Effects of elementary school students gender and grade level on bullying. American International Journal of Social Science, 2(7), 16-25. Retrieved from https://www.aijsnet.com/journal/vol_2_No_7_ocyober-2013/3.pdf

Manna, G., Falgares, G., Ingoglia, S., Como, M. R., \& Santis, S. D. (2016). The relationship between self-esteem, depression and anxiety: Comparing Vulnerability and Pear Model in Italian Contex. Mediterranean Journal of Clinical Psychology, 4(3), 2-17. Retrieved from https://www.researchgate.net/publication/315105739

Masselink, M., Van Rockel, E., \& Oldehinkel, A. I. (2018). Self-esteem in early adolescence 
as predictor of depressive symptoms in late adolescence and early adulthood: the mediating role of motivational and social factors. Journal of Youth and Adolescence, 47(5), 932-946. https://doi.org/10.1007/s10964-017-0727-z

Mello, L. M., \& Pinto, N. (2018) A study on the self-esteem and academic performance among the students. International Journal of Health Science and Pharmacy, 2(1), 1-7. http://dx.doi.org./10.5281/zenado.1156448.

Minev, M., Petrova, B., Mineva, K., Petkova, M., \& Strebkova, R. (2008). Self-esteem in adolescents. Travia Journal of Sciences, 16(2), 114-118. https://doi.org/10.15547/tjs.2018.02.007

Nurhayati, Rosmaiyadi, \& Buyung. (2017). Efforts to improve students' self-confidence using collaborative learning model. Journal Pendidikan Matematika Indonesia, 2(2), 57-62. https://doi.org/10.26737/jpmi.v2i2.223

Orth, U., \& Robins, R. W. (2014). The development of self-esteem. Current Directions in Psychological Science, 23(5), 381-387. https://doi.org/10.1177/0963721414547414

Raqqad, H. K., Bourini, E. S., Talahin, F. M., \& Aranki, M. E. (2017). The impact of school bullying on students' academic Achievements from teachers' point of view. International Education Students, 10(6), 44-50. https://doi.org/10.5539/ies.v10n6p44

Ratnasari, S. D., \& Andriansyah, A. S. (2014). Effect of self-confident and self-assessment for performance with social skill as moderating variables. Journal of Business and Management, 16(11), 43-47. https://doi.org/10.9790/487X-161164347

Rivers, I., Noret, N., Poteat, P., \& Ashurst, M. (2009). Observing bullying at school: The Mental health implications of witness status. American Psychological Association, 24(4), 211-223. https://doi.org/10.1037/a0018164

Robins, R. W., \& Trzesniewski, R. H. (2005). Self-esteem development across the life span. Current Direction in Psychology Science, 14(3), 158-162. https://doi.org/10.1111/j.0963-7214.2005.00353.x

Sari, I., Ekici, S., Sayer, F., \& Eskiller, E. (2015). Does self-confidence link to motivation? A study in field hockey athletes. Journal of Human Sports and Exercise, 10(1), 24-35. https://doi.org/10.14198/jhse.2015.101.03

Sharma, S., \& Agarwala, S. (2015), Self-esteem and collective self-esteem among adolescents: an interventional approach. Turkish Online Journal of Educational Technology, 8(1), 105-113. https://doi.org/10.5964/psyct.v8i1.121

Smith, P. (2016). Bullying: Definition, types, causes, consequences and intervention. Social and Personality Psychology Compass, 10(9), 519-532. https://doi.org/10.1111/spc3.12266

Turkmen, N., Dogkoz, H., Akgoz, S., Eren, B., Vural, P., \& Polat, O. (2013). Bullying among high school students. A Journal of Clinical Medicine, 8(2), 143-152. Retrieved from https://www.researchgate.net/publication/259474519 


\section{Macrothink}

Uba, I., Yaacob, S. N., Juhari, R., \& Talib, M. A. (2010). Effect of self-esteem on the relationship between depression and bullying among teenages in Malaysia. Asian Social Science, 6(12), 77-81. https://doi.org/10.5539/ass.v6n12p77

Wolke, D., Woods, S., Bloomfield, L., \& Karstadt, L. (2001). Bullying involvement in primary school and common health problems. Arch Dischild, 85, 197-201. https://doi.org/10.1136/adc.85.3.197

Zalya, J. et al. (2017). Students perceptions of school bullying and its impact on academic performance. A Longitudinal Look. Arch Argent Pediatr, 116(2), 216-226. https://doi.org/10.5546/aap.2018.eng.e216

\section{Glossary}

Bullied refers to someone who experiencing to be hurt or insult by the use force or verbal way

Self-esteem refers to beliefs of feelings that someone had in their self or self-confidence

\section{Appendix}

Appendix 1. Survey Questionnaire for the Instructions: Please put check mark to the blank provided corresponds to any number written above each item that will best describe your opinion by using the following code below.

\section{Bullied}

\begin{tabular}{l}
\hline Indicators \\
\hline 1. I was teased by my face in nasty ways \\
2. Lies and false rumors were told about me to others to hurt me \\
3. I was hurt by someone trying to break me up my relationship with friends \\
4. I was made to feel afraid/intimate by what someone said he/she do to me \\
5. I was deliberately hurt physically by someone and/or by a group ganging up on me \\
6. I was called names in nasty ways or name calling \\
7. Someone told me he/she wouldn't like me unless I did what he/she said \\
8. My things were deliberately damaged, destroyed, or stolen \\
9. I was teased by the used of my parent's names \\
10. Bullies are always looking fun at me
\end{tabular}

\section{Students' Self-Esteem}

\section{Indicators}

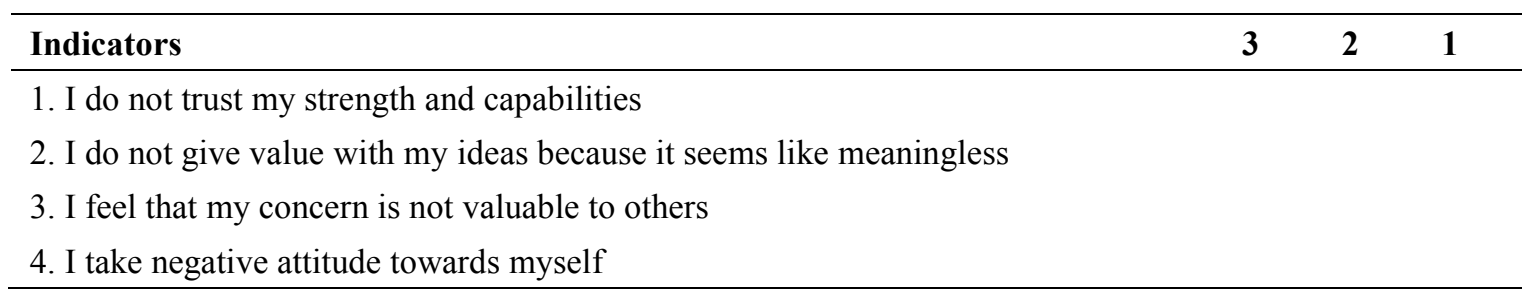


5. I feel that I don't have a number of good qualities

6. I am not able to do things as well as most people

7. All in all, I am inclined to feel that I am failure

8. I feel I do not have much to be proud of

9. I certainly feel useless at times

10. At times I think that I am not good at all

\section{Copyrights}

Copyright for this article is retained by the author(s), with first publication rights granted to the journal.

This is an open-access article distributed under the terms and conditions of the Creative Commons Attribution license (http://creativecommons.org/licenses/by/4.0/). 